\title{
Entrepreneurial Finance: Insights from English Language Training Market in Vietnam
}

\author{
Thanh-Hang Pham ${ }^{1,2, *} \mathbb{0}$, Manh-Toan Ho ${ }^{3,4} \oplus$, Thu-Trang Vuong ${ }^{4,5}$, Manh-Cuong Nguyen ${ }^{6}$ and \\ Quan-Hoang Vuong ${ }^{3,7}$ iD \\ 1 Faculty of Management and Tourism, Hanoi University, Km9 Nguyen Trai Road, Thanh Xuan, \\ Hanoi 100803, Vietnam \\ 2 School of Business, RMIT Vietnam University, Hanoi 100000, Vietnam \\ 3 Centre for Interdisciplinary Social Research, Phenikaa University, Yen Nghia Ward, Ha Dong District, \\ Hanoi 100803, Vietnam; toan.homanh@phenikaa-uni.edu.vn (M.-T.H.); \\ hoang.vuongquan@phenikaa-uni.edu.vn (Q.-H.V.) \\ 4 A.I. for Social Data Lab, Vuong \& Associates, 3/161 Thinh Quang, Dong Da District, Hanoi 100000, Vietnam; \\ thutrang.vuong@sciencespo.fr \\ 5 École Doctorale, Sciences Po Paris, 75337 Paris, France \\ 6 Faculty of International Studies, Hanoi University, Km9 Nguyen Trai Road, Thanh Xuan, \\ Hanoi 100803, Vietnam; manhcuongvhgd@gmail.com \\ 7 Centre Emile Bernheim, Université Libre de Bruxelles, B-1050 Brussels, Belgium \\ * Correspondence: hangpt@hanu.edu.vn
}

Received: 29 March 2020; Accepted: 11 May 2020; Published: 13 May 2020

\begin{abstract}
Entrepreneurship plays an indispensable role in the economic development and poverty reduction of emerging economies like Vietnam. The rapid development of technologies during the Fourth Industrial Revolution (Industry 4.0) has a significant impact on business in every field, especially in the innovation-focused area of entrepreneurship. However, the topic of entrepreneurial activities with technology applications in Vietnam is under-researched. In addition, the body of literature regarding entrepreneurial finance tends to focus on advanced economies, while mostly neglecting the contextual differences in developing nations. Therefore, this research contributes to these topics by investigating the main characteristics of a high potential market for entrepreneurs in Vietnam, which is the English language training market (ELTM). It also aims at indicating the impacts of technology on the entrepreneurial firms within this market, with an emphasis on financing sources. To answer the research questions, this study employs a qualitative analysis and conducts 12 in-depth, semi-structured interviews with entrepreneurs and researchers in the field. The key findings in our study highlight the main contributing factors to the growth of the market, both universally and context-specific for a developing nation like Vietnam. It also lists the leaders in each market segment and the industry's potential profit margin. The results also show that most entrepreneurs in the ELTM utilized private sources of finance rather than external ones, such as bank loans. It again confirms the idea from previous works that even with the rapid development of the economic and technological landscape, entrepreneurial activities in general barely benefit from additional sources of funding. However, it also points out the distinct characteristics of the ELTM that may influence these financing issues; for example, English training services usually collect revenues from customers before delivering their classes. This is of advantage for entrepreneurs in this area and helps significantly reduce the financial barriers. These findings, which are among the first attempts to contribute to a better understanding of entrepreneurial opportunities in the Industry 4.0 in Vietnam, provide valuable insights for policymakers and entrepreneurs, as well as investors.
\end{abstract}

Keywords: entrepreneurship; entrepreneurial finance; Vietnam; English training; entrepreneurial opportunities; edtech; Industry 4.0; finance performance; computational entrepreneurship 


\section{Introduction}

In Vietnam, entrepreneurship has been a major driver of the economy since the overall economic reform known as Doi Moi in 1986 (Vuong 2016, Vuong et al. 2019). The focus on economic renovation and open-door policies have opened up new opportunities for privately owned enterprises. Regardless of forms and sizes, these entrepreneurial ventures have contributed significantly to the development of the economy, as well as giving the people opportunities to have a better living standard (La and Vuong 2019, Andersen and Nielsen 2012). During the mid-1980s, GDP per capita stagnated between US\$200 and US\$300 (Vanham 2018) but soared to US\$6900 in 2017 (Central Intelligence Agency 2020). This leads to the rise of a middle class as a strong catalyst for increased consumer spending (McKinsey \& Company 2019), with significant changes in their purchasing behaviors, for example, more substantial investment in education for their children.

Additionally, in the era of globalization, emerging economies, including Vietnam, need to be open and integrated in terms of cross-border trade and investment, thus heightening the need to communicate interculturally using English as the lingua franca (Vuong and Napier 2015). As a result, during the past decades, English has gained its dominance as a foreign language in these nations.

However, for a considerable portion of the Vietnamese population, English proficiency remained limited, with an overall "low" English proficiency ranking compared to other countries (Tuoi Tre News 2019). Therefore, Vietnam's English language training market (ELTM) is considered as promising for entrepreneurial activities (EVBN 2018). The country has a population of nearly 100 million people, including $45.7 \%$ of people in the working-age and another 38\% from 0-24 years old who have substantial demand for the English language training services (Central Intelligence Agency 2020). This is further supported by a strong commitment by the government to promote English as the primary foreign language (Trines, Stefan, BMI 2019, Bui and Nguyen 2016). Additionally, education has always played a central role in Vietnam's society and culture, as it is seen as the ultimate path to success and as a way to make the family proud (EVBN 2018). The rise of different movements in the education sector, namely outbound education (Trines, Stefan), English as a medium of instruction in universities (BMI 2019) and new transnational or advanced programs in higher education (EVBN 2018), have all contributed to the development of ELTM as a potential landscape for entrepreneurial activities.

Within this landscape of favorable external factors, the ELTM has long developed in the country, with a large number of independent teachers as well as English centers. Recently, with the rapid advancement in technology in the Fourth Industrial Revolution, i.e., Industry 4.0, the education sector in general and the ELTM market, in particular, have witnessed the rapid emergence of new business models to satisfy diverse customer needs. These so-called edtech startups, or education technology, have attracted significant investment, totaling up to US\$55 million in 2018, followed by a three-fold rise to US\$150 million in 2019 (Tech Collective 2019). Overall, edtech was among the top five most profitable areas for Vietnamese start-ups, with ELTM as one of the most attractive segments. As some typical examples, various firms operating in this market have obtained funding from foreign capital ventures, namely TOPICA Edtech Group with US\$50 million (Russell 2018), Yola English teaching school with US\$10 million (Nguyen 2019) or ELSA artificial intelligence (AI)-powered startup with US\$7 million (Russell 2019). The emergence of these external financial sources may also signal a crucial change in the entrepreneurial finance of the market. As finance is considered as the lifeblood of a business, firms' financial management will also be drastically affected by these upcoming changes in the source of funding (Horák 2016).

Given the rapidly changing landscape of the ELTM in Vietnam, which also represents the same movement in various other developing economies, this research aims at investigating the impacts of technology on the ELTM in Vietnam with a focus on entrepreneurial financing issues and trends in the market. To address the research objective of an exploratory study, this study employs qualitative analysis and conducts 12 in-depth, semi-structured interviews with entrepreneurs and researchers in the field. 


\section{Literature Review}

\subsection{Entrepreneurial Finance Research}

First, to examine a phenomenon, researchers need to define it and put some boundaries around it. Therefore, in this paper, entrepreneurship is defined as an activity that involves the discovery, evaluation, and exploitation of opportunities to introduce new goods and services, ways of organizing, markets, processes, and raw materials, through organizing efforts that previously had not existed (Venkataraman 1997, Shane and Venkataraman 2000, Shane 2003). This definition is chosen for its popularity in the research field, as well as the inclusiveness that is appropriate for a market consisting of diverse entrepreneurial forms, such as independent teachers, English training centers, or technology-based products and services. Amongst various aspects, such as human capital, social capital, or entrepreneurial behavior that influence entrepreneurial performance (Santarelli and Tran 2013, Tipu and Arain 2011), financial constraints are frequently cited as the main barrier to entrepreneurship (Andersen and Nielsen 2012). By definition, entrepreneurial finance focuses on studying the financial aspects of entrepreneurship, such as financial performance and resource allocation, etc., which deviates from traditional finance studies (Paré et al. 2009). Overall, entrepreneurial finance is a rapidly growing research field, in which different research domains can be found. In the scope of this paper, we would like to focus on the area of alternative sources of capital, as the ability to access capital is among the most critical issues facing entrepreneurial firms.

The state of the art of entrepreneurial finance has recently been examined by several scientists. Denis (2004) stated that as these firms do not yet generate profits and mostly lack tangible assets, they usually cannot rely on debt financing, or in other words, bank loans. Therefore, three primary sources of outside equity financing tend to be utilized, including venture capital funds, angel investors, and corporate investors. The first one refers to "limited partnerships in which the managing partners invest on behalf of the limited partners" (Denis 2004, p. 304). It is stated that an essential difference between venture capital and bank finance is that a VC often provides substantial managerial contributions to the venture (De Bettignies and Brander 2007). The second one refers to "high net worth" people who use their own money to invest in several firms (Denis 2004, p. 304). Lastly, corporate investors conduct investment activities on behalf of their shareholders to aim for strategic and/or financial objectives. It is further stated that, although the accurate division of the total funding into each source is difficult, all these three funding sources make a substantial capital contribution to the entrepreneurial firms (Denis 2004).

In Cumming and Groh (2018) work, they stated several Google Scholar trends for different search terms in entrepreneurial finance, including debt, IPO (initial public offering), venture capital, private equity, angel, entrepreneurial finance, trade credit and crowdfunding (Cumming and Groh 2018). Among these, IPOs and venture capital have been the focus of research in the area from 2000 to 2016, and interest in crowdfunding was basically non-existent until 2020, but since then has grown at a remarkable rate (Cumming and Groh 2018). While IPO is regarded as a critical exit event of venture capital investments, crowdfunding is defined as an entrepreneur's means of collecting capital from an external source represented by a large community (Belleflamme et al. 2014), even before direct sales (Miglo 2020). Cole and Sokolyk (2018) extend previous papers and focus on the two kinds of debt which exist for start-ups: debt originated by the venture (business debt) and debt originated by the entrepreneur (personal debt) (Cole and Sokolyk 2018). The authors find that the distinction between personal debt and business debt is important. Better quality start-ups are more likely to obtain business debt, and such debt is associated with higher survival and revenue growth rates (Cole and Sokolyk 2018).

Bellavitis et al. (2017) discussed these sources in more detail. The study indicated the usual financing cycle, which started with the three "Fs", representing friends, family, and "fools", followed by business angels, VCs, and capital markets (Bellavitis et al. 2017). Entrepreneurs looking to raise seed finance usually turned to their close ties. They developed a prototype, approached the first clients, and hopefully generated revenues. Once these initial milestones were achieved, entrepreneurs started 
enlarging their circle of financiers with business angels. These wealthy and well-connected individuals usually provided the capital to expand. At this stage, the venture was supposed to grow substantially to be appealing to institutional investors such as VCs, including both domestic and cross-border ones (Bradley et al. 2019). VC funding and connections fuel strong growth domestically and internationally. Once the start-up raised VC funding, the entrepreneur and the investors shared the goal of reaching an IPO or selling the company to a large corporation. The majority of highly successful companies followed a similar funding cycle (Berger and Udell 1998). Nowadays, however, this funding cycle has to be re-conceptualized. Entrepreneurs in science and technology start-ups can raise finance from new sources, including accelerators and incubators, proof-of-concept centers, university-based seed funds, and crowdfunding platforms. Undeniably, VC, and angels are important sources of financing for entrepreneurial ventures. However, only an extremely select group of entrepreneurial firms with high-growth ambitions are able to attract VC or angel financing. Moreover, interestingly, studies have suggested - contrary to the commonly held view in entrepreneurial finance literature- that banks and debt finance represent a major source of financing for entrepreneurial firms (Cassar 2004, Zarutskie 2006, Huyghebaert and Van de Gucht 2007).

Overall, these works, together with various others, call for more research into entrepreneurial finance to shed light on newly emerging phenomena, given the practical importance of entrepreneurial finance for developed, as well as developing economies. Furthermore, with the dominance of studies examining entrepreneurship in advanced countries (Vuong et al. 2020, Meyer et al. 2014), additional insights into the phenomena within emerging economies' context may also be of critical value to advance the discipline.

\subsection{Entrepreneurship Research Regarding Vietnam Context}

The study by Vuong et al. (2020) highlighted the strong wave of entrepreneurial activities in Vietnam (Vuong et al. 2020). It was also stated that cultural influence might be the reason why much of the non-innovative working culture in enterprises across the country has persisted so long. It is common for entrepreneurs to start businesses by initially copying the model from other existing firms and amending them later to adjust to the changing environment. Findings have also revealed that the majority of business founders in Vietnam base their initial settings on personal intuition and pure luck, without any analytical plan being carried out (Vuong et al. 2020). Strikingly, the study indicates that although Industry 4.0 and Artificial Intelligence have become the buzzwords in both governmental agendas and public discussions in recent years (Viet Nam News 2018), the technological application is nearly absent from much of the research on entrepreneurship in Vietnam. From 2008 to 2018, there have only been three research articles that can be classified into the topic of technological utilization, namely Thao and Swierczek (2008), Le et al. (2018); Le et al. (2012). The first one investigates the way small and medium-sized travel agencies, in the role of business customers, perceive the benefits as well as limitations of Internet use relating to relationship development and loyalty with their service suppliers (Thao and Swierczek 2008). The second one examines technological gaps and the factors affecting variations in the technical efficiency of small and medium enterprises (SMEs) in Vietnam (Le et al. 2018). The last one employs an adaptation of the technology—organization-environment framework and test a model of e-commerce adoption in a number of internal and external factors identified in empirical studies (Le et al. 2012). However, none of those studies mention high-tech applications such as machine learning, artificial intelligence, etc.

In another recent systematic review of 111 entrepreneurship studies regarding Vietnam's context, the results show that from 2013, the promotion of entrepreneurship in Vietnamese society has pushed the interest of Vietnamese people, and consequently, researchers and research productivity (Vuong et al. 2020). Before 2012, academics were not enthusiastic about entrepreneurship; the increase of public attention on the subject has driven their focus to the field. The study also pointed at the difference between Vietnamese entrepreneurship research compared to the global landscape. While the former tends to examine practical aspects of entrepreneurial activities, the latter focuses more on 
the cognitive and theoretical aspects of entrepreneurship. In particular, 40 articles, accounting for more than one-third of this body of literature, are concerned with managing firms' capital and economic efficiency. These studies highlight the heavy reliance of Vietnamese SMEs on financial capital, so much that capital constraint was seen as the biggest concern for enterprises. Besides, the study by Vuong et al. (2020) again highlights the lack of research on some important topics, especially in terms of technology application (Vuong et al. 2020).

These studies conclude that the status of entrepreneurship research in Vietnam is still in its infancy, both in terms of output as well as the content. On the one hand, the findings show a substantial interest in the aspect of entrepreneurial finance in Vietnam's context; on the other hand, it also calls for more studies on under-researched topics on entrepreneurship, including practical matters such as technology application.

\subsection{Overview of Vietnam's English Language Training Market}

Vietnam's ELTM is considered as a potential area for entrepreneurial opportunities. According to BMI Global, in 2019, 437 projects with a total registered foreign investment of USD 4.3 billion were reported in the education and training sector, the majority of which has been directed towards the English language training area (BMI 2019). In the two biggest cities of Vietnam, namely Hanoi and Ho Chi Minh cities, the number of registered language centers have increased significantly. In 2018, Hanoi had approximately 500 English language centers, and this number soared by $80 \%$ to around 900 in the following year (Department of Education and Training Hanoi 2018, 2019). In Ho Chi Minh city, there was a growth of 50\% from 400 English centers in 2017 to 600 in 2019 (Department of Education and Training 2017, 2019). This shows the timely initiatives of entrepreneurs to grasp opportunities in this market.

Various factors have contributed to the significant development of the ELTM in Vietnam. The economic outlook in the medium term is positive, with the GDP growth rate in the last two years exceeding 7\% (The World Bank Vietnam 2020). Furthermore, Vietnam continues to actively integrate into the global economy by joining WTO in 2007 and various free trade agreements with other countries (Central Intelligence Agency 2020) The country has attracted a steady inflow of foreign direct investment (FDI), reaching US\$15.5 billion in 2018 (The World Bank 2020). These factors contribute to the rapid growth of demand in language training, as both domestic and international companies prefer candidates with higher proficiency in the foreign language. Together with that, an emerging middle class, currently accounting for $13 \%$ of the population, is expected to amount to 44 million people in 2020 and reach $26 \%$ of the population by 2026 (The World Bank Vietnam 2020, ANT Consulting 2020). This middle-income group creates strong purchasing power in the market, such as for studying and traveling abroad (EVBN 2018).

Having a population of nearly 99 million people, Vietnam is considered as a nation of the "golden age," with $45.7 \%$ people in the working-age. Also, the number of students from kindergarten to higher education adds up to almost 23 million, many of whom have English as a compulsory subject at school, as the medium of instruction or as a critical asset for recruitment opportunities. With policies urging for the enhancement of English proficiency for Vietnamese people, this creates an enormous market for entrepreneurs. In terms of technological use, this young population has excessive usage of the Internet. In 2018, there were 64 million Internet users and a digital economy value of US\$ 9 billion. The e-commerce value accounts for 1.7\% of GDP, with a value of US\$3.5 billion (Anh 2020).

Moreover, Vietnam's society and culture, which is rooted in Confucianism, has always valued education as the key to success (Vuong et al. 2018, 2020, 2020). Teachers are highly regarded in Vietnam and parents are willing to go to great lengths to ensure that their children receive a good education, as commented by Minister of Education Phung Xuan Nha: "Vietnamese parents can sacrifice everything, sell their houses and land just to give their children an education" (McKinsey \& Company 2019). In terms of the education service, it is stated that the private education section is preferred over public schools because it is perceived as providing better teaching methods as well as improved results 
for learners (EVBN 2018). This perspective results in a robust demand for 'non-public', 'supplementary', and 'overseas' services.

Regarding government policies, in the early 2000s, English was claimed to become a compulsory subject for all students throughout the country (Prime Minister 2001). Since then, the government has been opening doors for a broad spectrum of international universities, corporations, and non-government organizations (NGOs) to collaboratively promote English in Vietnam. Higher investment incentives also apply for foreign investment in this sector than other foreign investment forms (British Business Group Vietnam 2018). In particular, the Vietnamese government specifies that education is one of the prioritized areas; as a result, investment in the field can enjoy a $10 \%$ tax reduction for the entire lifetime of operation, application for all projects. Enterprises in this sector also benefit from four years of corporate income tax (CIT) exemption and five years of 50\% reduction on payable CIT (BMI 2019).

In terms of potential customers, the major customer segments of English language training services all show positive signals. For K-12 students, Vietnam's curriculum for junior and senior secondary schools requires English to be taught as a compulsory subject from grade 6 to grade 12. A pilot program was implemented in 2010 and 2011 to teach the language as a compulsory subject from Grade 3. Overall, the importance of English can be seen through its vital role in final and entrance exams at middle school and tertiary levels (Bui and Nguyen 2016). Another contributing factor is the emergence of international schools in Vietnam, with a total of 123 English-medium schools, accommodating more than 66,000 students and earning tuition fee income of around US\$634 million (BMI 2019). For higher education, Vietnam is regarded as one of the most dynamic markets for studying abroad in the world, with an explosion of the number of outbound students by 680 percent during the period from 1999 to 2016 (Trines, Stefan). It was reported that there were more than 946,000 students in 2017 (UNESCO Institute of Statistics 2020). It is further predicted that student mobility is guaranteed to grow in the coming years, particularly in the context of Vietnam's internationalization in both the economy and the education system (Trines, Stefan). Domestically, new university programs besides the standard one, namely high-quality, advanced, and transnational programs (EVBN 2018), have been introduced, most of which use English as a medium of instruction and provide opportunities to transfer to partner universities abroad. Therefore, applicants are required to have a certain English level, and these programs also make the language a requirement for students to graduate. These outbound, as well as domestic, trends in education all enhance the importance of English and motivate learners to find ways to improve their level of the language.

As for the workforce, English has always been regarded as an essential skill in employment and promotion opportunities. Additional attributes, including language proficiency and soft skills, are highly appreciated in the country, because of their ability to increase individuals' employability (EVBN 2018). The report Vietnam 2035: toward prosperity, creativity, equity, and democracy, jointly prepared by the Ministry of Planning and Investment and the World Bank Group, asserts that the country must develop its human capital in terms of technical skills and especially strong English language skills. By getting a better level of English proficiency, particularly in specialized topics, it will help to narrow the skill gaps of Vietnam's labor force compared to the international standards, which will result in better opportunities for the nation (World Bank Group 2016).

These favorable conditions for ELTM contrast with the situation of Vietnamese people's limited English level. The country's English skills were listed in the low-proficiency category in 2019 in The English Proficiency Index, with data from more than 2,300,000 test-takers (Tuoi Tre News 2019, Education First 2019). Additionally, the average English score of high school graduates in the national exam in 2019 was only 4.36/10, with a below-average score in two-thirds of the students (Phan 2019). As for the workforce, Vietnam was ranked 57th out of 76 countries surveyed in the Total Workforce Index Report in 2019, a significant fall from the previous year ranking of 43rd. One of the three challenges faced by the nation's labor force is stated to be low English proficiency. The limited language level remains one barrier that prevents the country from moving upstream in the global value chain 
(Nguyen 2020). These data show a low level of English proficiency among Vietnamese people, which signals a need to improve their skills by soliciting formal and non-formal education services.

Based on the discussed factor, Vietnam's ELTM is considered as highly promising for entrepreneurial opportunities. Therefore, more efforts should be made to investigate this market and its characteristics, as well as the particular entrepreneurial finance aspect of start-ups.

\subsection{Research Questions}

Given the context of Vietnam's ELTM, as well as the lack of studies about Vietnam's entrepreneurship, especially with a focus on financial and technology application aspects, this research aims to answer the following research questions:

1. What are the main characteristics of ELTM in Vietnam?

2. What are the impacts of technology on entrepreneurial firms, especially entrepreneurial finance, in ELTM in Vietnam?

\section{Method and Material}

\subsection{Method}

To answer the research questions, given the infancy of the entrepreneurship literature about Vietnam's context, especially with no previous work focusing on technology application in ELTM, this study adopts an exploratory qualitative design. In particular, semi-structured in-depth interviews were used to collect information from two groups, namely education researchers and entrepreneurs in the ELTM. This research design is chosen because semi-structured schedules enable the examination of spontaneous expressions, reducing pre-conceptualized boundaries, and simultaneously keeping to the interview agenda (Cavaco et al. 2005). In addition, the flexibility of a semi-structured interview with exploratory questions helps a researcher to understand the world from the participant's perspective (Cavaco et al. 2005, Charlton and Barrow 2002, Robson 2002; Kvale 1996).

Firstly, the research team had to identify a small group of target participants on a convenience basis. These respondents were supposed to have diverse perspectives on the research topic. Then, they were asked to recommend other participants for interviews. The selection criteria were that the education researchers have insights into the subject matter, and the entrepreneurs have been directly involved in the ELTM. This is known as the snowball sampling technique (Quinn Patton 2002), which is cost-effective and quite efficient in getting a suitable sample group for a qualitative investigation. However, the main drawback of this sampling method is its non-probability and non-randomness. As a result, conclusions produced relate only to the participants' perceptions and situations, but that does not mean that the insights revealed are irrelevant to an understanding of the experiences of a larger group. It is crucial, though, that any transfer of ideas from this research to other settings is done by the reader, and not by the investigator (Lincoln and Guba 1985). The interviews took place during February and March 2020. The research team continued the data collection until the saturation point of data, where no novel insights emerged from the interviewees. Nearly 20 interviews were conducted, of which some had to be canceled, as the participants did not meet the selection criteria. Finally, 12 interviews were chosen for the data analysis of this research.

A thematic analysis was used to organize the interview material in relation to the research questions (Banister 2011). The main themes were examined and discussed informally, which gave insight into how to approach the analysis. The discourse was then categorized into a concise and structured format, which gave a clear overview of the main themes (Robson 2002); this, in turn, allowed the comparison of differences and similarities between respondents. Throughout the analysis, reference was made to the original transcripts. 


\subsection{Material}

The detailed profile of 12 participants is presented in Table A1, in which each person receives a number to protect their anonymity. The form of interviews was implemented in the most preferred way by the participants. Most of them were conducted face-to-face in person. Several others were conducted by telephone, and in one case, the questions were sent via email to the participant, and answers were sent back. Regardless of the form, the interviews were successful in getting a "rich, detailed, and concrete description" (Quinn Patton 2002). This is crucial to a successful qualitative investigation.

Based on instructions from Spradley (2016), most of the questions in the interviews were open-ended, with no limits on how each participant would share their perspectives (Quinn Patton 2002). Following the participants' responses, more questions can be asked to clarify or further investigate these responses.

To answer the first research question about the main characteristics of ELTM in Vietnam, the following questions were asked:

- What factors have been affecting the development of ELTM in Vietnam?

- What companies are the market leaders in ELTM in Vietnam?

- What is the average profit margin of enterprises participating in the ELTM in Vietnam?

- How do you evaluate the ELTM in Vietnam in the next five years?

To answer the second research question about the impacts of technology on entrepreneurial firms, especially entrepreneurial finance in ELTM in Vietnam, the following questions were asked:

- How does technology affect the ELTM in Vietnam?

- How does technology affect entrepreneurial opportunities in the ELTM in Vietnam?

- How do enterprises in the ELTM in Vietnam finance their businesses?

- Does technology change the way enterprises in the ELTM in Vietnam finance their businesses?

Some questions were only asked for participants who were the business owners of firms operating in the ELTM, including:

- How does technology affect your firm's business operations?

- How did you finance your business?

- Does technology affect the way you finance your business?

The language used in all interviews was Vietnamese, as this is the native language for both the participants and the authors. For telephone and in-person interviews, with permission from the interviewees, the authors kept a digital record for each of them for further reference. During the meetings, all necessary care was taken to make sure that the respondents were not exposed to any risks, in terms of both emotional and reputational aspects.

\section{Findings}

In this part, key themes from the interviews are presented. Participants are referred to as researchers or entrepreneurs. To preserve the authenticity of participants' comments, translation into English of the actual words or phrases used by participants are reported.

\subsection{Main Characteristics of ELTM in Vietnam}

The themes related to the main characteristics of the ELTM in Vietnam can be divided into two parts, namely the factors affecting the growth of ELTM and market leaders, as well as the profit margin of the ELTM.

\subsubsection{Factors Affecting the Growth of ELTM}

The participants were invited to comment on the driving forces of the ELTM in recent years. It was the case that one participant after another reported customer demand as one of the most critical factors 
affecting the rapid development of the ELTM. It was further explained by Participant 2 that for children, the demand mainly comes from parents, especially mothers, who have the tendency to discuss their children's schooling and education. This phenomenon is further promoted via discussions on online platforms, previously as online forums, and more recently as social media groups, where ideas can be shared easily. This results in the fact that customer demands are more easily expressed, whereas recommendations or reviews of education services can be more rapidly shared among group members. For teenagers, students, and adults, the influence of social media was also highlighted, for example, in participant 11 's comment:

Facebook pages affect the development of ELTM as they share inspirational posts every day, so even if one person does not have the motivation in the first place when they continuously see people and friends around them learn English, they also have the tendency to be eager to learn.

Another factor that was reported by many participants is the impact of globalization and the strong economic integration of Vietnam into the global market. Because of this significant trend, English, as a lingua franca, has become an essential tool for any worker in the economy. Participant 6's view reflected the ideas reported by many of other participants:

Firms target the working people that want to improve their English skills. The ultimate goal is to get better job opportunities.

Furthermore, government policies were referred to by more than half of the participants. In accordance with the setting mentioned above, the National Foreign Language Project 2020 was considered one particularly crucial program to enhance the role of English as a foreign language in the education system.

The prevailing view of participants was that technology is another significant contributing factor to the growth of the market. It affects various aspects of the market, such as promoting the products and services more effectively, as well as organizing the learning experience more quickly.

Comments made by some participants also revealed that the availability of learning and teaching material was another factor influencing the growth of ELTM. With the abundance of materials both online and in printed editions, teachers and language training centers have a variety of choices about which one suits their teaching purpose and learning path for students. The significant reduction in price, especially with online sources, also results in families being more willing to buy books and materials for their children.

Interestingly, one participant saw the development of online teaching partly as a result of terrible traffic in big cities in Vietnam, as reported:

The reason why online English training can invade the market and grow is because of terrible traffic, especially in big cities. Learners cannot stand going such a long way through many traffic congestion points. They are afraid of traffic accidents, kidnapping, and other dangers on the street. Children nowadays are precious to their parents, so safety is the most important thing.

Overall, the participants' accounts regarding factors that affect the development of ELTM focused on four main aspects: customer demand, globalization, government policies, and technology. For each customer segment, primarily based on age groups, other additional factors help contribute to the growth of the market over recent decades.

\subsubsection{Market Leaders and Profit Margin}

It was widely commented that there was no reliable source of information and statistics about the industry, so it was not transparent enough to state which company is the market leader. However, in each market segment, some brands were mentioned by various participants. In the online ELTM, 
TOPICA Native was reported by all participants as the leading firm in the sector of general English for working people. Participant 4 regarded TOPICA as the "game-changer" of the market, as it changes customers' habits remarkably. Besides, Monkey Junior was considered the most popular application of learning English for kids. On the other hand, in terms of offline market penetration, APAX, with 123 branches, was claimed to be the biggest chain of English training centers. Various participants also reported on another criterion of evaluation, which is the long history of the brand, in which some names appear to be repeated in the accounts, including British Council, Apollo, Language Link, and ILA.

The participants were also invited to comment on the average profit margin of firms operating in the ELTM in Vietnam. Interestingly, the accounts here were quite diverse. For traditional business models, the dominating comment was that profit margin ranges from $25 \%$ to $30 \%$. However, some participants even reported a range from $20 \%$ to $50 \%$, and when asked further to explain the reason for such a big gap, participant 5 responded by saying:

Many English language training centers have brilliant strategies to cut costs. The main reason is that they have a low-cost human resource. For a center, hiring foreign teachers is the biggest cost item, with an hourly rate from US $\$ 22$ to US $\$ 30$. If the centers hire $100 \%$ foreign teachers, and also provide the service of outsourcing these teachers, only this service helps them break even and bring about additional profits besides the profits from their own classes. However, if firms spend resources on recruiting foreign teachers even though this is not their strength, the profit margin will be quite low.

For high-tech firms in the ELTM in Vietnam, comments from the participants were even more polarized. On the one hand, a small group of participants reported positively about this segment, for example, participant 2 also stated that "for firms focusing on online markets, the profit margin is around $40 \%-45 \%$." On the other hand, participants who are running firms in this market segment shared different ideas; in particular, participant 3 reported that "online teaching models currently cannot generate profits." Participant 6 expressed a similar point of view, adding that:

Start-up businesses do not focus on profit margin. Instead, their focus is on market growth and scale. Therefore, revenues generated will be used for reinvesting, which is different from the traditional business model. However, the revenue growth rate will be high, around $20 \%$ monthly.

Overall, it can be seen from participants' comments that there is no dominating market leader in the whole ELTM in Vietnam, and each company mentioned appears to have competitive advantages in certain aspects. Together with that, the profit margin of offline business models is quite favorable if firms can manage to survive after the early stage of establishment. On the other hand, online-focused companies now prioritize growth and market share rather than gaining profits.

\subsection{Impacts of Technology on Entrepreneurial Firms and Entrepreneurial Finance in ELTM in Vietnam}

The themes related to the impacts of technology on entrepreneurial firms and entrepreneurial finance in ELTM in Vietnam can be divided into several parts. First, the impacts on entrepreneurial opportunities are discussed; then, the effects on operations and financing of firms in the ELTM are discussed.

\subsubsection{Technology and Entrepreneurial Opportunities in English Language Training Market}

When asked about entrepreneurial opportunities in ELTM in Vietnam, most of the participants evaluated the opportunities as "promising" and "high potential." Participant 2 even commented that "the entry barrier to this market is nearly zero." On the other hand, two participants reported the same positive viewpoint about setting up a business in the market, yet added that surviving in this fiercely competitive market is a different thing. 
Participant 1 shared a slightly different idea that the opportunities now are more complicated than previously, and only firms that can take advantage of technology and adopt effective business models will be able to grasp these opportunities.

In terms of market segments that are the most promising, participants' points of view were quite diverse. Participant 6 reported that:

In all segments of the market, there is no dominating firms or brands. Opportunities exist because the demand for learning is high.

Participant 3 expressed a different point of view that traditional, offline-focused business models are much more comfortable than the online segment because, in the latter, even big corporations are still struggling, for example, TOPICA Native.

From another perspective, participant 9 saw the matter as highly promising opportunities for niche demand, for instance, customizing products and services and offering individualized care for each learner. Large enterprises that focus on economies of scale may find it challenging to meet this type of demand, therefore leaving these niche segments open for entrepreneurs.

The participants' accounts regarding the application of technologies strongly suggested that these new advancements are significantly useful for entrepreneurs. For example, some participants provided details about the ease and convenience of running a business with a single device, which was impossible just a few years ago. Small business owners or independent teachers can reach customers/students, market their services, provide consultations, and deliver lessons on their smartphones, with the support of different technological tools. Moreover, it was not uncommon for the participant to refer to technology integration as a way to cut costs, such as the costs of printing and teaching material. Students can use online sources to support their learning or even replace traditional textbooks and worksheets. The existence of a gap between different customer segments was, however, acknowledged. One participant was especially detailed in his remarks.

In big cities, technology applications can be useful. However, in rural areas, people's perceptions are very different; they never let their children use technologies in that way, nor do they have the equipment and facilities to do so.

Participant 6, though running a company developing applications to help kids learn English, reported explicitly that

Starting up a business does not necessarily rely on technologies. I have friends who use traditional business models and still win their niche market. However, technologies can help firms to scale up rapidly.

Not immediately evident in these remarks, but consistent with the tone in which they were communicated, was the message that combines both offline and online features was a promising option for starting up in the ELTM market.

Though the matter was not explored systematically with the participants, it did generally appear that many participants thought about technology applications and solutions, not as direct competitors of traditional language centers. Participant 6 saw the matter as:

Technology helps explore new customer segments, increase customer demand, and expand the market as a whole. English learners always face the problem of pricing and affordability. The costs to learn at English centers are too high. Some people who can afford that service cannot find nearby centers to send their kids, either. Technology enables learners to study anywhere, anytime, at affordable prices.

In short, participants generally assessed entrepreneurial opportunities in ELTM in Vietnam positively. Technology plays the role of primarily creating a platform for those opportunities, or partly facilitate the more accessible and cheaper establishment of firms in the market. 


\subsubsection{Technology and Operations of Firms in English Language Training Market}

Another critical theme emerged from the in-depth interviews with participants: the impacts of technology on operations of firms in ELTM in Vietnam. Participant 1's remarks captured most of the elements referred to by others:

Technological applications primarily affect two critical aspects of business: management and delivering products/services to customers.

In particular, all of the participants who are business owners reported that they are applying technology in their business operations to some extent, from the primary level, such as communicating with students via email and correcting student homework via Google docs, to using business management systems to coordinate activities among departments. Participant 4 reported that:

Soft-wares for customer relationship management (CRM) or enterprise resource planning (ERP) helps manage learners and internal control of firms more effectively. These systems coordinate all departments of the company so that the owners can monitor the operations of those departments and detect where the problems come from.

Participant 2 want one step further, claiming that:

Cramming models with one teacher and hundreds of students gradually deteriorated, not so popular as in former times. Franchising one center into a chain of centers becomes more manageable with the help of technology, not only in terms of learning and teaching, but it is about technologies in operations - center organization, customer service, and sales.

In addition, participant 9 highlighted the use of social networks as a highly useful marketing tool for firms and entrepreneurs in the market. She stated that

Even young teachers can start their own business and using these online channels to promote their personal brands.

Several other participants made similar comments.

In terms of delivering the products or services, various participants regarded technology as a means to improve the quality of English language training services. For online teaching, in former times, teachers and students used applications like Skype, which assisted the real-time conversation and videos of both sides. Technology advancement nowadays enables more functions to facilitate the interaction between teachers and learners, such as the participation of all students in the class, sharing the screen of any members, or direct writing and drawing on the screen. Participant 3 commented on this improvement as:

This makes the learning experience more "real." Learners will feel like this is not so much different from offline learning, and they will gradually build trust in this form of delivery.

Additionally, of interest here is that all the participants mentioned the COVID-19 pandemic as a critical factor in promoting online learning and creating changes in the way businesses develop their products. For more details, the outbreak has resulted in school and educational service closure in most parts of the country since early February 2020 (La et al. 2020). Some participants reported the challenges, such as participant 5 :

This outbreak [negatively] affects all centers, especially those without any online teaching platform like us.

In short, participants reported the useful application of technology in firms' operations, as well as the way in which they deliver their services and products to customers. The outbreak of COVID-19 globally in 2020 also contributed significantly to the wider spread of this application. 


\subsubsection{Technology and Financing of Firms in English Language Training Market}

Interestingly, a consensus was reached amongst participants about the source of financing among firms in ELTM. In particular, the majority of participants commented that the source of funding for entrepreneurial firms depends on the size of the firm as well as the nature of business. All the participants claimed that small firms obtained their initial capital from the personal saving of the founder or founding team, as well as loans from their family and friends. On the other hand, big-sized enterprises or chains of centers usually raise capital from investment funds. For technology-based companies, it is claimed by some participants that the funding also comes from raising money from angel investors and then investment funds, however, "successful cases in raising this kind of capital in Vietnam are rare." (Participant 6)

Participant 4 commented:

The source of financing is another advantage of running businesses in education, as it does not require substantial capital. The starting point can be minimal, but in a successive way, [which means that] we can collect money before the start of each class, for example. Also, this is an intangible product, the better we do branding for it, the more value it gets.

Another participant further commented:

As a source of financing, bank loans are minimal and insignificant. The reason is that the requirements and procedures [to get a bank loan] are so complicated.

More strikingly, for the majority of the participants, their original source of funding was actually from their savings and support from their families and close friends. Even the founder of an edtech company reported receiving no financial support from any other sources, other than those during their development. Some participants went even one step further, claiming that they started from zero capital. The reason they gave for this irregular opinion is that in the education business, revenues are usually collected before delivering the service. Therefore, this amount of money can be used immediately to cover the costs. The hourly rent of a classroom is also readily available in Vietnamese markets, enabling entrepreneurs to set up their services with little cost. By utilizing this advantage, many young independent teachers have been able to start their own business from literally nothing.

Regarding the impacts of technology on funding source of enterprises in the English training market in Vietnam, participant 2 reported that:

There is no change in the funding sources; it only helps businesses to acquire users and growing market share. Access to financing sources will become more accessible with a larger market share.

Many other participants shared similar viewpoints. Only two participants emphasized that technology would directly impact the online part of the market, in particular edtech companies, which need substantial sources of capital. Participant 6 also mentioned another aspect that venture capital companies would engage in the market, as they prefer business models that are scalable and have the potential to grow exponentially.

Overall, comments of participants about financing sources of firms in ELTM in Vietnam revealed that in the first place, startups mainly based on their savings or loans from family and friends to finance their newly established firms. Technology-based models may seek investments from venture capital later when they reach a certain level of market share and growth. Therefore, generally speaking, technology does not change the funding sources for ELTM, except for the edtech firms.

\section{Discussion and Implications}

\subsection{Discussion}

Among the various factors that influence economic growth, it is widely accepted that entrepreneurship plays a crucial role in fostering growth and improved standards of living (Ahlstrom 
et al. 2019, Ahlstrom 2010, Urbano et al. 2019). As a typical example, Vietnam's "economic miracle", as commented by the World Economic Forum (World Economic Forum 2020), has been relying substantially on SMEs, whose growth in number and capital over the past two decades has cemented entrepreneurship as the backbone of the economy (Vuong et al. 2020). However, research on entrepreneurship in this fast-growing economy is limited in terms of both research output and content (Vuong et al. 2020). Especially when it comes to the topic of technology integration, few works that examine the impacts of this inevitable trend on entrepreneurial firms can be found (Vuong et al. 2020, 2020). On the other hand, the body of literature regarding entrepreneurial finance also lacks diversity in terms of an institutional, socio-economic and cultural context, with the current focus on advanced industrialized English- speaking countries such as the United States, the United Kingdom and Canada (Vuong et al. 2020). Therefore, this research contributes to the body of Vietnamese entrepreneurship literature as well as entrepreneurial finance by investigating the ELTM in Vietnam under the impacts of technology utilization, with a focus on financing issues and trends in the market. The ELTM market was chosen for its high potential; as long as the demand for language training persists and the country's language performance remains average, there is market space for entrants who possess expertise in the field (EVBN 2018).

Generally, the macro-environmental factors of Vietnam positively affect the development of the market, especially regarding government policies to promote English and Vietnamese cultural tradition, which values education as the key to success. More particularly, the primary customer segments of the market have witnessed supportive trends. For K-12 students, the national curriculum for all levels of schools gradually integrated English in terms of both earlier starting grade, as well as more emphasis on its importance. The emergence of international schools in various cities and provinces in the country also means that more and more students will study subjects in English. For higher education students, the strong trends of studying abroad, English as a medium of instruction, and new university programs all contributed to more student demand for English teaching products and services. Last but not least, better employment and promotion opportunities have motivated the workforce to improve themselves. Therefore, the ever-increasing demand from these customer segments for English skills in the country presents enormous possibilities for start-ups and investment in English training centers that meet these needs (Vietnam Economic Times 2020).

To investigate, the research questions were as follows:

1. What are the main characteristics of ELTM in Vietnam?

2. What are the impacts of technology on entrepreneurial firms, especially entrepreneurial finance, in ELTM in Vietnam?

The study's exploratory qualitative design aims at documenting the opinions and perspectives of a selected sample of researchers and entrepreneurs to shed light on these issues. The selection criteria were that the education researchers have insights into the subject matter, and the entrepreneurs have been directly involved in the ELTM. These participants, therefore, cannot represent all stakeholders' perspectives at large. However, they would be able to provide insights related to several matters of specific interest to the investigation, including factors affecting the growth of ELTM, its market leaders and profit margin, technology, and entrepreneurial opportunities, operations of firms, and their financing in ELTM in Vietnam. The data for investigation were obtained by individual, in-depth, semi-structured interviews with the selected participants.

Various themes that emerged from participants' accounts have been highlighted in the paper.

To answer the first research question, participants' comments about the main characteristics of Vietnam's ELTM were collected. Participants, when asked about the main driving forces for the ELTM, listed major factors, such as customer demand, globalization, government policies, and technology. These are consistent with the literature regarding the overview of the ELTM in Vietnam (EVBN 2018, Trines, Stefan, BMI 2019, Bui and Nguyen 2016, British Business Group Vietnam 2018). Interestingly, some specific points directly related to the context of a developing country were also made; for example, 
traffic congestion and accidents were reported, by participants, to be contributing to the choice of online learning mode for a group of customers. This shows that socio-economic and cultural factors do have an influence on entrepreneurial activities by creating new customer demand. Additionally, similar to the market overview, ELTM is evaluated by most participants as a promising industry that offers potential opportunities for entrepreneurs (EVBN 2018, Trines, Stefan, British Business Group Vietnam 2018). With the favorable profit margin from at least $20 \%$ and little sensitivity to the fluctuation of the macro-economic environment, the market appears to be a good investment option during both good and bad times. The integration and application of technology have created even more potential for individuals who can take advantage of these advancements to create a platform for their businesses or to facilitate business operations as well as the delivery of products and services to customers. However, the use of more updated Industry 4.0 technologies, such as virtual reality or artificial intelligence, is still limited.

To have a better understanding of the market landscape, the question about the market leaders was raised. This type of information currently lacks from the body of literature about ELTM in Vietnam. Though no official statistics and market reports are available to the public, participants shared somehow similar accounts about the market leaders. The brand names mentioned were TOPICA Native for the online English teaching for adults, Monkey Junior for online English application for kids, APAX Leaders as the biggest chain of centers, and British Council Vietnam, Apollo English, Language Link Vietnam and ILA as having a long history and reputation for quality. These provide valuable models for entrepreneurs to investigate and analyze before entering the market. The closer look at financing sources as well as financial management of these firms may also be of interest to entrepreneurs or investors to understand the typical business models of leading Vietnamese companies in ELTM.

More details about these companies can be found in Table 1.

To answer the second research question, participants' accounts regarding the impacts of technology on entrepreneurial firms, especially entrepreneurial finance in ELTM in Vietnam, were reported. Generally, technological applications affect two critical areas of ELTM: the way business operations are managed, and the way firms deliver their services and products to customers. More or less, all business owners participating in the study reported the use of technologies in both aspects. However, besides various favorable factors, the application of Industry 4.0 in ELTM in Vietnam has several obstacles. The infrastructure of the country is still limited, which causes interruption during the interaction between teachers and students. This may result in students' loss of eagerness and deterioration of the learning atmosphere within the class. Additionally, if online learning is conducted for kids, it requires parents to spend time and effort to support their kids along the way. Many Vietnamese parents are not familiar with and willing to do this. In terms of geographical areas, the development of online English learning appears to be healthy only in big cities, where Internet facilities, as well as consumer readiness, are much better than less-developed areas.

In terms of entrepreneurial finance in Vietnam's ELTM, the consensus among participants about the entrepreneurial financing source in ELTM was a striking feature of the study, revealing that the majority of small-sized entrepreneurial firms in this market relied on personal savings or loans from family and friends. This is similar to the argument by Bellavitis et al. (2017) that the financing cycle usually started with the three "Fs" representing friends, family, and "fools" (Bellavitis et al. 2017). The personal loans from family and friends can be referred to as personal debt (Cole and Sokolyk 2018). This shows that the start-ups in ELTM seem to be of insufficient quality, as better quality entrepreneurial firms have a better chance to get business debt, and such debt is associated with higher survival and revenue growth rates (Cole and Sokolyk 2018). On the other hand, this study's findings are inconsistent with the results of several previous studies, mainly conducted in developed economies. The three primary sources of outside equity financing by Denis (2004), namely venture capital funds, angel investors, or corporate investors, were not the preferred funding form by Vietnamese entrepreneurs in this market (Denis 2004). This may stem from the infancy stage of the ELTM in Vietnam, in which most entrepreneurial firms are in its early stages. In fact, the only firm in this market that has been 
listed on the stock exchange is Apax Holdings Investment Joint Stock Company (stock code IBC on Ho Chi Minh Stock Exchange), which is also the owner of the largest English language training center chain in Vietnam, APAX Leaders (Nhung 2020). Similar to this market situation, participants' comments regarding entrepreneurial finance in Vietnam's ELTM mentioned the only exceptions of not using personal savings and loans as the chain of centers and edtech firms. These ventures might seek substantial sources of funding from the beginning to provide resources for them to adopt the strategy of market penetration and to rapidly gain market share. Therefore, they may seek funding from angel investors or venture capital, not only to gain access to financial resources but also to take advantage of their connections and managerial contributions (De Bettignies and Brander 2007, Bellavitis et al. 2017). However, it should be noted that chains of English centers typically start from one single center only. Hence, it is likely that, only after reaching a certain level of development, they would be interested in attracting more finance from external sources.

Table 1. Leading companies in ELTM in Vietnam.

\begin{tabular}{|c|c|c|c|c|c|c|}
\hline No. & Company & Website & $\begin{array}{c}\text { Year of } \\
\text { Establishment }\end{array}$ & $\begin{array}{l}\text { Number of } \\
\text { Branches }\end{array}$ & Main Product Lines & $\begin{array}{c}\text { Main Target } \\
\text { Customer Segment }\end{array}$ \\
\hline 1 & TOPICA Native & $\begin{array}{l}\text { https:// } \\
\text { topicanative. } \\
\text { edu.vn/ }\end{array}$ & 2014 & N/A & $\begin{array}{l}\text { Communicative English for beginners } \\
\text { Intensive communicative English } \\
\text { Communicative English } \\
\text { (for corporates) }\end{array}$ & $\begin{array}{l}\text { Working people with } \\
\text { communication } \\
\text { purposes }\end{array}$ \\
\hline 2 & Monkey Junior & $\begin{array}{l}\text { https://www. } \\
\text { monkeyjunior. } \\
\text { vn/ }\end{array}$ & 2014 & N/A & $\begin{array}{c}\text { Monkey Junior } \\
\text { Money Stories } \\
\text { Monkey Math } \\
\text { VMonkey }\end{array}$ & Kids $0-10$ years old \\
\hline 3 & APAX Leaders & $\begin{array}{l}\text { https://www. } \\
\text { apaxleaders. } \\
\text { edu.vn/ }\end{array}$ & 2015 & 123 & $\begin{array}{c}\text { Apax explorer } \\
\text { Apax challenger } \\
\text { Apax Conqueror } \\
\text { Apax } 4.0\end{array}$ & $\begin{array}{l}\text { 4-18-year-old } \\
\text { students }\end{array}$ \\
\hline 4 & $\begin{array}{l}\text { British Council } \\
\text { Vietnam }\end{array}$ & $\begin{array}{l}\text { https://www. } \\
\text { britishcouncil. } \\
\text { vn/en }\end{array}$ & $\begin{array}{l}2002 \text { (open first ELT } \\
\text { courses in Hanoi and } \\
\text { Ho Chi Minh City) }\end{array}$ & 5 & $\begin{array}{c}\text { English for primary } \\
\text { English for secondary (grades } 6-9 \text { ) } \\
\text { English for upper secondary and } \\
\text { IELTS } \\
\text { English for IELTS preparation } \\
\text { English for adults } \\
\end{array}$ & $\begin{array}{c}\text { Kids from } 6 \text { years old } \\
\text { Adults }\end{array}$ \\
\hline 5 & Apollo English & https://apollo.e & 1995 & 39 & $\begin{array}{c}\text { Apollo English Junior } \\
\text { Apollo English } 360 \\
\text { Teacher Training }\end{array}$ & $\begin{array}{c}\text { Kids from } 3 \text { years old } \\
\text { Adults } \\
\text { Teachers }\end{array}$ \\
\hline 6 & $\begin{array}{l}\text { Language Link } \\
\text { Academic }\end{array}$ & $\begin{array}{l}\text { https: } \\
\text { //llv.edu.vn/ }\end{array}$ & 1996 & 10 & $\begin{array}{c}\text { English for very young learners } \\
\text { English for young learners } \\
\text { English for teens } \\
\text { English for university test preparation } \\
\text { English for IELTS } \\
\text { English for professionals }\end{array}$ & $\begin{array}{l}\text { Kids from } 3 \text { years old } \\
\text { Adults } \\
\text { Teachers }\end{array}$ \\
\hline 7 & ILA Vietnam & $\begin{array}{l}\text { https: } \\
\text { //ila.edu.vn/ }\end{array}$ & N/A & 46 & $\begin{array}{c}\text { English for young learners } \\
\text { English for adults } \\
\text { English for corporate communication } \\
\text { ILA Maths } \\
\text { ILA OSC } \\
\text { English Overseas Summer }\end{array}$ & $\begin{array}{c}\text { Kids from } 3 \text { years old } \\
\text { Adults }\end{array}$ \\
\hline
\end{tabular}

Interestingly, comments from the group of independent teachers who started their businesses from virtually no financial sources suggested the possibilities for individuals without resource constraints to accessing the entrepreneurial opportunities in this market with the help of technologies in Industry 4.0. This is consistent with the idea that in this era of computational entrepreneurship, entrepreneurs who have expertise in this field can have a more comfortable and cheaper way to realize their opportunities (Vuong 2019). This insight helps to shed light on the current trends of many individuals who face financial source constraints, yet still established and developed their businesses successfully in the ELTM in Vietnam. One may say that Industry 4.0 has brought about opportunities that may never have existed in the past so that entrepreneurs from any corner of the world can gain access to a broad base of customers and persuade these customers to buy their products or services.

On the other hand, participants' comments showed that except for edtech companies, technology does not change the funding sources of ELTM. Instead, it helps businesses to acquire customers and grow market share, which in turn supports the access to sources of finance. In other words, regarding entrepreneurial finance, amid Industry 4.0, start-ups in ELTM in Vietnam mostly begin with private 
sources of funding and, through the development process, self-fund their businesses. Only firms seeking expansion of scale, such as opening a chain of centers or rapidly penetrating the market with their education technologies, may ask for external financial sources.

These findings are in line with previous works about the financing issues of Vietnamese entrepreneurial firms. Nguyen et al. (2015) commented that the majority of SMEs are micro-enterprises with limited access to resources, such as advanced technology and formal credit (Nguyen et al. 2015). Despite their significant contributions to social and economic development, SMEs are often regarded as "the missing middle" - they are usually not the subject of interest for commercial banks. At the same time, their loans might be too large to borrow from microfinance institutions. Therefore, the most critical factor that impedes the performance of SMEs in Vietnam is the lack of capital. The authors further indicated that firms in the service sector have a lower probability of borrowing by $9 \%$ compared to industry and trade (Nguyen et al. 2015). In the ELTM market, this may be due to the fact that tangible assets, namely facilities such as classroom equipment, tables, and chairs, etc., are not the most critical resource of the firms operating in this market. The most valuable assets are intangible, including intellectual property such as the self-made syllabus or textbooks, as well as the high-quality human resource of dedicated and qualified teachers.

In another study focusing on microenterprises in Vietnam, Thai and Ngoc (2010) found out that most microentrepreneurs have to reply to their savings, partner's contributions, and borrowing from their family and friends to fund their business (Thai and Ngoc 2010). Most of them do not get funding from financial institutions. Even in the case of obtaining bank loans, these amounts could cover merely a small part of the investment needed to realize their business ideas (Thai and Ngoc 2010). These findings are similar to what is happening in the ELTM market. It again confirms the idea that, even with the rapid development of the economic and technological landscape, entrepreneurial activities in general barely benefit from additional sources of funding. The traditional finance sources which mostly come from personal resources still dominate. These call for more vigorous actions from the government policies to promote and support entrepreneurs, so that start-ups can develop more strongly in the fast-growing economy.

However, the study's results also point out the distinct characteristics of the ELTM that may influence these financing issues. English training services usually collect revenues from customers before delivering their classes. The initial investment for facilities is also rather modest compared to other start-up businesses. This is of advantage for entrepreneurs in this area and helps significantly reduce the financial barriers.

\subsection{Implications}

This paper suggests important implications for policymakers and entrepreneurs, as well as investors. The insights from the study can help contribute to policy formation and implementation amid Industry 4.0. Policymakers can have an overview of the technological impacts on ELTM, thereby developing appropriate legal frameworks to support the development of newly emerged market segments, especially those with a high level of technology applications. The entrepreneurial financing options and trends discussed can also provide input for the development of these frameworks. It is recommended that the authorities plan and implement more supportive policies, especially in terms of requirements and access to financing sources, such as loan banks, so as to encourage and promote entrepreneurship in the country.

For entrepreneurs and investors, the study reveals valuable insights, so that these stakeholders can evaluate investment opportunities in the field, more effectively regarding the influences of Industry 4.0. Different options of entrepreneurial finance were also discussed, which help provide input for business plans or investment decisions, which may lead to a higher chance of success in these initiatives. 


\section{Limitations and Future Research Directions}

Despite the contribution, we fully acknowledge the limitations of this paper. Firstly, because of the nature of exploratory research, we are faced with a shortage of backing in the extant literature. Besides, with qualitative research design, the results of this study cannot be generalized to the broader populations. Due to the limited number of researchers in the education field who understand the situation of ELTM in Vietnam, the mix of participants is somewhat uneven, which may cause a biased view towards the matters of interest. The market situation of ELTM in Vietnam also keeps changing rapidly at the time of writing, with new trends and new enterprises, as well as the bankruptcy of existing firms, especially during the COVID-19 pandemic.

We understand that exploratory qualitative work has limited scientific validity, so, in the future, a more rigorous quantitative research design may be conducted to provide such validity. Researchers may also consider adopting theories or frameworks regarding technological application or adoption, to investigate, in more detail, the changing nature of the ELTM in Vietnam. Business models of typical firms in the ELTM can also be analyzed to observe the impacts of technology on financial management, as well as other business components and their outcomes. Last but not least, quantitative research design with statistical analysis should be employed to test a different hypothesis about the market and the potential entrepreneurial opportunities.

Author Contributions: Conceptualization, T.-H.P., M.-T.H., and Q.-H.V.; Data curation, T.-H.P. and M.-C.N.; Formal analysis, T.H.P., M.-C.N. and Q.H.V.; Investigation, T.-H.P.; Methodology, T.-H.P., M.-T.H. and T.-T.V.; Project administration, T.-H.P., M.-T.H. and M.-C.N.; Supervision, Q.-H.V.; Writing-original draft, T.-H.P.; Writing - review and editing, M.-T.H., T.-T.V. and Q.-H.V. All authors have read and agreed to the published version of the manuscript.

Funding: This research received no external funding.

Conflicts of Interest: The authors declare no conflict of interest. 


\section{Appendix A}

Table A1. Profile of participants.

\begin{tabular}{|c|c|c|c|}
\hline Participant Number & Researcher/Entrepreneur & Gender and Age Bracket in Years & Details \\
\hline 1 & Researcher & $\begin{array}{l}\text { Male } \\
35-39\end{array}$ & $\begin{array}{l}\text { More than } 20 \text { peer-reviewed articles in international books and journals as well as multiple } \\
\text { reports and conference papers written in Vietnamese and English for scholarly audiences globally }\end{array}$ \\
\hline 2 & Researcher & $\begin{array}{l}\text { Male } \\
30-34\end{array}$ & $\begin{array}{l}\text { Seven peer-reviewed articles in international books and journals as well as multiple reports and } \\
\text { conference papers written in Vietnamese and English for scholarly audiences globally }\end{array}$ \\
\hline 3 & Entrepreneur & $\begin{array}{c}\text { Female } \\
35-39\end{array}$ & $\begin{array}{l}\text { An English language training center established from } 2009 \text { with more than } 3000 \text { learners, } \\
\text { currently focusing on primary and secondary students, applying blended learning from } 2015\end{array}$ \\
\hline 4 & Entrepreneur & $\begin{array}{c}\text { Female } \\
35-39\end{array}$ & $\begin{array}{l}\text { An English language training center established from } 2017 \text { with a total of around } 2000 \text { learners, } \\
\text { focusing on training job readiness for university students together with English skills }\end{array}$ \\
\hline 5 & Entrepreneur & $\begin{array}{c}\text { Male } \\
30-34\end{array}$ & $\begin{array}{l}\text { An English language training center from } 2017 \text { located in suburban areas of Hanoi with } 700 \\
\text { students studying in the center now. }\end{array}$ \\
\hline 6 & Entrepreneur & $\begin{array}{l}\text { Male } \\
35-39\end{array}$ & Applications to support learning foreign languages for kids $0-10$ years old \\
\hline 7 & Entrepreneur & $\begin{array}{l}\text { Male } \\
30-34\end{array}$ & $\begin{array}{c}\text { An independent English instructor who operates small-sized classes, focusing on IELTS test } \\
\text { preparation in both online and offline modes }\end{array}$ \\
\hline 8 & Entrepreneur & $\begin{array}{c}\text { Female } \\
30-34\end{array}$ & $\begin{array}{l}\text { A university lecturer who started an English language training center from } 2012 \text { with small-sized } \\
\text { classes for kids and teenagers }\end{array}$ \\
\hline 9 & Entrepreneur & $\begin{array}{c}\text { Female } \\
30-34\end{array}$ & $\begin{array}{l}\text { An independent English instructor who is currently in the United States and runs online classes, } \\
\text { focusing on IELTS test preparation and communicative English }\end{array}$ \\
\hline 10 & Entrepreneur & $\begin{array}{l}\text { Female } \\
40-44\end{array}$ & $\begin{array}{l}\text { An English language training center franchised from 2015, providing services both to the center's } \\
\text { customers as well as to public-owned schools }\end{array}$ \\
\hline 11 & Entrepreneur & $\begin{array}{c}\text { Female } \\
25-29\end{array}$ & $\begin{array}{l}\text { An independent English instructor started teaching from } 2016 \text { and had more than } 1000 \text { students, } \\
\text { focusing on IELTS test preparation }\end{array}$ \\
\hline 12 & Entrepreneur & $\begin{array}{l}\text { Male } \\
30-35\end{array}$ & $\begin{array}{l}\text { An English language training center established in } 2012 \text { with services ranging from providing } \\
\text { training courses to corporations to cooperating with public-owned schools and teaching students } \\
\text { at the center. }\end{array}$ \\
\hline
\end{tabular}




\section{References}

Ahlstrom, David. 2010. Innovation and growth: How business contributes to society. Academy of Management Perspectives 24: 11-24.

Ahlstrom, David, Amber Y. Chang, and Jessie S. T. Cheung. 2019. Encouraging entrepreneurship and economic growth. Journal of Risk and Financial Management 12: 178. [CrossRef]

Andersen, Steffen, and Kasper Meisner Nielsen. 2012. Ability or finances as constraints on entrepreneurship? evidence from survival rates in a natural experiment. The Review of Financial Studies 25: 3684-710. [CrossRef]

Anh, Huong. 2020. Mastering Technology for Vietnam's Growth. Available online: https://www.vir.com.vn/ mastering-technology-for-vietnams-growth-67693.html (accessed on 24 February 2020).

ANT Consulting. 2020. The Middle Class of Vietnam Increased Sharply. Available online: http: //www.antconsult.vn/news/the-middle-class-of-vietnam-increased-sharply.html\#ixzz6E6kFi9uG (accessed on 24 February 2020).

Banister, Peter. 2011. Qualitative Methods in Psychology: A Research Guide. New York: McGraw-Hill Education.

Bellavitis, Cristiano, Igor Filatotchev, Dzidziso Samuel Kamuriwo, and Tom Vanacker. 2017. Entrepreneurial finance: New frontiers of research and practice. Venture Capital 19: 1-16. [CrossRef]

Belleflamme, Paul, Thomas Lambert, and Armin Schwienbacher. 2014. Crowdfunding: Tapping the right crowd. Journal of Business Venturing 29: 585-609. [CrossRef]

Berger, Allen N., and Gregory F. Udell. 1998. The economics of small business finance: The roles of private equity and debt markets in the financial growth cycle. Journal of Banking $\mathcal{E}$ Finance 22: 613-73. [CrossRef]

BMI. 2019. Education in Vietnam. Available online: https://bmiglobaled.com/Market-Reports/Vietnam/education (accessed on 12 May 2020).

Bradley, Wendy A., Gilles Duruflé, Thomas. F. Hellmann, and Karen E. Wilson. 2019. Cross-border venture capital investments: What is the role of public policy? Journal of Risk and Financial Management 12: 112. [CrossRef]

British Business Group Vietnam. 2018. Vietnam-2018 Education. Hanoi: British Business Group Vietnam.

Bui, Thuy Thi Ngoc, and Hoa Thi Mai Nguyen. 2016. Standardizing english for educational and socio-economic betterment-a critical analysis of english language policy reforms in Vietnam. In English Language Education Policy in Asia. New York: Springer, pp. 363-88.

Cassar, Gavin. 2004. The financing of business start-ups. Journal of Business Venturing 19: 261-83. [CrossRef]

Cavaco, Afonso. M., J. P. Sousa Dias, and Ian P. Bates. 2005. Consumers' perceptions of community pharmacy in Portugal: A qualitative exploratory study. Pharmacy World and Science 27: 54-60. [CrossRef]

Central Intelligence Agency. 2020. The World Factbook Vietnam. Available online: https://www.cia.gov/library/ publications/resources/the-world-factbook/ (accessed on 24 February 2020).

Charlton, Gina S., and Corinne J. Barrow. 2002. Coping and self-help group membership in Parkinson's disease: An exploratory qualitative study. Health $\mathcal{E}$ Social Care in the Community 10: 472-78.

Cole, Rebel A., and Tatyana Sokolyk. 2018. Debt financing, survival, and growth of start-up firms. Journal of Corporate Finance 50: 609-25. [CrossRef]

Tech Collective. 2019. Vietnam's Emerging Edtech Startups. Available online: https://techcollectivesea.com/2019/ 12/03/vietnams-emerging-edtech-startups/ (accessed on 23 April 2019).

Cumming, Douglas, and Alexander Peter Groh. 2018. Entrepreneurial finance: Unifying themes and future directions. Journal of Corporate Finance 50: 538-55. [CrossRef]

De Bettignies, Jean-Etienne, and James A. Brander. 2007. Financing entrepreneurship: Bank finance versus venture capital. Journal of Business Venturing 22: 808-32. [CrossRef]

Denis, David J. 2004. Entrepreneurial finance: An overview of the issues and evidence. Journal of Corporate Finance 10: 301-26. [CrossRef]

Department of Education and Training Hanoi. 2018. List of Licensed Foreign Language and Informatics Centers. Available online: http://sogd.hanoi.gov.vn/trung-tam-ngoai-nha-truong/danh-sach-cac-trung-tam-ngoaingu-tinh-den-ngay-30122018-cm1099-6896.aspx (accessed on 22 March 2020).

Department of Education and Training Hanoi. 2019. List of Licensed Foreign Language and Informatics Centers. Available online: http://sogd.hanoi.gov.vn/trung-tam-ngoai-truong/danh-sach-cac-trung-tam-ngoai-ngutin-hoc-tinh-den-31122019-tren-dia-ban-thanh-c1099-9851.aspx (accessed on 22 March 2020). 
Department of Education and Training. 2017. List of Licensed Foreign Language and Informatics Centers. Available online: https://hcm.edu.vn/thong-bao/danh-sach-cac-trung-tam-ngoai-ngu-tin-hoc-da-duoc-capphep-tinh-den-ngay-12-tha-cmobile41012-57342.aspx (accessed on 22 March 2020).

Department of Education and Training. 2019. List of Licensed Foreign Language and Informatics Centers. Available online: http://edu.hochiminhcity.gov.vn/chuyen-muc/danh-sach-cac-trung-tam-ngoai-ngu-tinhoc-duoc-cap-phep-cap-nhat-den-ngay-12032-cmobile41743-61861.aspx (accessed on 22 March 2020).

Education First. 2019. EF English Proficiency Index, 9th ed. Lucerne: Education First.

Lincoln, Yvonna S., and Egon G. Guba. 1985. Naturalistic Inquiry. Beverley Hills: Sage.

EVBN. 2018. Education in Vietnam Edition 2018. Ho Chi Minh City, Vietnam: EU-Vietnam Business Network.

Horák, Josef. 2016. Does Industry 4.0 Influence Efficiency of Financial Management of a Company. Pargue: The 10th International Days of Statistics and Economics. Available online: https://msed.vse.cz/msed_2016/article/ 174-Horak-Josef-paper.pdf (accessed on 12 May 2020).

Huyghebaert, Nancy, and Linda M. Van de Gucht. 2007. The Determinants of Financial Structure: New Insights from Business Start-ups. European Financial Management 13: 101-33. [CrossRef]

La, Viet-Phuong, and Quan-Hoang Vuong. 2019. Bayesvl: Visually Learning the Graphical Structure of Bayesian Networks and Performing MCMC with 'Stan'; The Comprehensive R Archive Network (CRAN). Available online: https://cran.r-project.org/web/packages/bayesvl/index.html (accessed on 12 May 2020).

La, Viet-Phuong, Thanh-Hang Pham, Manh-Toan Ho, Minh-Hoang Nguyen, Khanh-Linh P. Nguyen, Thu-Trang Vuong, Hong-Kong T. Nguyen, Trung Tran, Quy Khuc, Manh-Tung Ho, and et al. 2020. Policy Response, Social Media and Science Journalism for the Sustainability of the Public Health System Amid the COVID-19 Outbreak: The Vietnam Lessons. Sustainability 12: 2931. [CrossRef]

Le, Viet, Xuan-Binh Vu, and Son Nghiem. 2018. Technical efficiency of small and medium manufacturing firms in Vietnam: A stochastic meta-frontier analysis. Economic Analysis and Policy 59: 84-91. [CrossRef]

Le, Van Huy, Frantz Rowe, Duane Truex, and Minh Q. Huynh. 2012. An empirical study of determinants of e-commerce adoption in SMEs in Vietnam: An economy in transition. Journal of Global Information Management 20: 23-54. [CrossRef]

McKinsey \& Company. 2019. Seizing the Fast-Growing Retail Opportunity in Vietnam. Available online: https://www.mckinsey.com/ \{\}/media/mckinsey/industries/retail/our\%20insights/how\%20companies\% 20can\%20seize\%20opportunity\%20in\%20vietnams\%20growing\%20retail\%20market/seizing-the-fastgrowing-retail-opportunity-in-vietnam.ashx (accessed on 24 April 2020).

Meyer, M., D. Libaers, B. Thijs, K. Grant, W. Glänzel, and K. Debackere. 2014. Origin and emergence of entrepreneurship as a research field. Scientometrics 98: 473-85. [CrossRef]

Miglo, Anton. 2020. Crowdfunding in a Competitive Environment. Journal of Risk and Financial Management 13: 39. [CrossRef]

Nguyen, Thi Bich Ngoc. 2019. Kaizen PE Strikes First Deal in Vietnam, Invests \$10m in YOLA. Available online: https://www.dealstreetasia.com/stories/kaizen-pe-yola-147120/ (accessed on 22 April 2020).

Nguyen, Ha. 2020. Total Workforce Index 2019-3 Challenges for Vietnam's Labor. Available online: https: //www.vietnam-briefing.com/news/total-workforce-index-2019-3-challenges-vietnams-labor.html/ (accessed on 24 February 2020).

Nguyen, Thi Nhung, Christopher Gan, and Baiding Hu. 2015. An Empirical Analysis of Credit Accessibilty of Small and Medium Sized Enterprises in Vietnam. Banks and Bank System 10: 34-46.

Nhung, Hong. 2020. Apax Holdings Lists on HoSE. Available online: http://vneconomictimes.com/article/bankingfinance/apax-holdings-lists-on-hose (accessed on 26 April 2020).

Paré, Jean-Louis, Jean Rédis, and Jean-Michel Sahut. 2009. The development of entrepreneurial finance research. International Journal of Business 14: 283.

Phan, Nghia. 2019. Vietnam's English Proficiency Drops in 2019 Ranking. Vnexpress International. Available online: https://e.vnexpress.net/news/news/vietnam-s-english-proficiency-drops-in-2019-ranking-4008398. html (accessed on 12 May 2020).

Kvale, Steinar. 1996. Interviews: An Introduction to Qualitative Research Interviewing. Thousand Oaks: Sage. 
Prime Minister. 2001. Directive No.14/2001/CT-TTg, Promulgated by the Prime Minister of Government, on Renovation of the General Education Program in Execution of Resolution No. 40/2000/QH10 of the National Assembly. Available online: https://thuvienphapluat.vn/van-ban/giao-duc/Chi-thi-14-2001-CT-TTg-doimoi-chuong-trinh-giao-duc-pho-thong-thuc-hien-Nghi-quyet-40-2000-QH10-47782.aspx (accessed on 12 May 2020).

Quinn Patton, Michael. 2002. Qualitative Research and Evaluation Methods. Thousand Oaks: Sage.

Robson, Colin. 2002. Real World Research: A Resource for Social Scientists and Practitioner-Researchers. Oxford: Blackwell Oxford, vol. 2.

Russell, Jon. 2018. Topica raises \$50M for its online learning services in Southeast Asia. Available online: https://techcrunch.com/2018/11/27/topica-raises-50m/ (accessed on 23 April 2020).

Russell, Jon. 2019. Gradient Ventures, Google's AI Fund, Leads \$7M Investment in English Learning app Elsa. Available online: https:/techcrunch.com/2019/02/26/gradient-ventures-elsa-7-million/ (accessed on 22 April 2020).

Santarelli, Enrico, and Hien Thu Tran. 2013. The interplay of human and social capital in shaping entrepreneurial performance: The case of Vietnam. Small Business Economics 40: 435-58. [CrossRef]

Shane, Scott Andrew. 2003. A General Theory of Entrepreneurship: The Individual-Opportunity Nexus. Cheltenham: Edward Elgar Publishing.

Shane, Scott, and S. Venkataraman. 2000. The promise of entrepreneurship as a field of research. Academy of Management Review 25: 217-26. [CrossRef]

Spradley, James P. 2016. Participant Observation. Long Grove: Waveland Press.

Thai, Mai Thi Thanh, and Ho Thuy Ngoc. 2010. Microentrepreneurship in a transitional economy: Evidence from Vietnam. In Contemporary Micro-Enterprise: Concepts and Cases. Cheltenham: Edward Elgar, pp. 32-48.

Thao, Hoang Thi Phuong, and Fredric William Swierczek. 2008. Internet use, customer relationships and loyalty in the Vietnamese travel industry. Asia Pacific Journal of Marketing and Logistics 20: 190-210. [CrossRef]

The World Bank Vietnam. 2020. Vietnam Overview. Available online: https://www.worldbank.org/en/country/ vietnam/overview (accessed on 24 February 2020).

The World Bank. 2020. Theoretical Framework. Available online: https://data.worldbank.org/indicator/BX.KLT. DINV.CD.WD (accessed on 25 April 2020).

Tipu, Syed Awais Ahmad, and Faisal Manzoor Arain. 2011. Managing success factors in entrepreneurial ventures: A behavioral approach. International Journal of Entrepreneurial Behavior E Research 17: 534-60.

Trines, Stefan. Education in Vietnam. Available online: https://wenr.wes.org/2017/11/education-in-vietnam (accessed on 24 February 2020).

Tuoi Tre News. 2019. English proficiency of Vietnamese hits five-year low: EF report. Tuoi Tre News, November 6.

UNESCO Institute of Statistics. 2020. Education: Outbound Internationally Mobile Students by Host Region. Available online: http://data.uis.unesco.org/Index.aspx?queryid=172 (accessed on 27 February 2020).

Urbano, David, Sebastian Aparicio, and David Audretsch. 2019. Twenty-five years of research on institutions, entrepreneurship, and economic growth: What has been learned? Small Business Economics 53: 21-49. [CrossRef]

Vanham, Peter. 2018. The Story of Viet Nam's Economic Miracle. Available online: https://www.weforum.org/ agenda/2018/09/how-vietnam-became-an-economic-miracle/ (accessed on 26 February 2020).

Venkataraman, S. 1997. The Distinctive Domain of Entrepreneurship Research. In Advances in Entrepreneurship, Firm Emergence, and Growth. Edited by Jerome Katz and R Brockhaus. Greenwich: JAI Press, pp. 119-38.

Viet Nam News. 2018. PM Pledges to Realise Industry 4.0 Opportunities. Available online: https://vietnamnews.vn/ economy/451777/pm-pledges-to-realise-industry-40-opportunities.html\#rSRPJ6mkrhiQ6qA9.99 (accessed on 25 April 2020).

Vietnam Economic Times. 2020. Key Requirement. Available online: http://vneconomictimes.com/article/vietnamtoday/key-requirement (accessed on 27 March 2020).

Vuong, Quan Hoang. 2016. Impacts of geographical locations and sociocultural traits on the Vietnamese entrepreneurship. SpringerPlus 5: 1189. [CrossRef]

Vuong, Quan-Hoang. 2019. Computational entrepreneurship: From economic complexities to interdisciplinary research. Business Perspectives 17: 117-29. [CrossRef]

Vuong, Quan Hoang, and Nancy. K. Napier. 2015. Acculturation and global mindsponge: An emerging market perspective. International Journal of Intercultural Relations 49: 354-67. [CrossRef] 
Vuong, Quan-Hoang, Quang-Khiem Bui, Viet-Phuong La, Thu-Trang Vuong, Viet-Ha T. Nguyen, Manh-Toan Ho, Hong-Kong T. Nguyen, and Manh-Tung Ho. 2018. Cultural additivity: Behavioural insights from the interaction of Confucianism, Buddhism and Taoism in folktales. Palgrave Communications 4: 143. [CrossRef]

Vuong, Quan-Hoang, Thi-Hanh Vu, Quang-Hung Doan, and Manh-Tung Ho. 2019. Determinants of Vietnamese footwear exporting firms' market selection: A multinomial logistic analysis of panel data. Heliyon 5: e02582. [CrossRef] [PubMed]

Vuong, Quan-Hoang, Viet-Phuong La, Thu-Trang Vuong, Hong-Kong T. Nguyen, Manh-Tung Ho, and Manh-Toan Ho. 2020. What have Vietnamese scholars learned from researching entrepreneurship? A Systematic review. Heliyon 6. [CrossRef] [PubMed]

Vuong, Quan-Hoang, Viet-Phuong La, Thu-Trang Vuong, Phuong Hanh Hoang, Manh Toan Ho, Manh Tung Ho, and Hong Kong T. Nguyen. 2020. Multi-faceted insights of entrepreneurship facing a fast-growing economy: A literature review. Open Economics 3: 25-41. [CrossRef]

Vuong, Quan-Hoang, Manh-Tung Ho, Hong-Kong T. Nguyen, Thu-Trang Vuong, Trung Tran, Khanh-Linh Hoang, Thi-Hanh Vu, Phuong-Hanh Hoang, Minh-Hoang Nguyen, Manh-Toan Ho, and et al. 2020. On how religions could accidentally incite lies and violence: Folktales as a cultural transmitter. Palgrave Communications 6: 82. [CrossRef]

Vuong, Quan-Hoang, La Viet-Phuong, Nguyen Minh-Hoang, Ho Manh-Toan, Ho Manh-Tung, and Peter Mantello. 2020. Improving Bayesian statistics understanding in the age of Big Data with the bayesvl R package. Software Impacts 4: 100016. [CrossRef]

World Bank Group. 2016. Vietnam 2035 Toward Prosperity, Creativity, Equity, and Democracy. Washington, DC: World Bank Group, Available online: http://hdl.handle.net/10986/23724 (accessed on 12 May 2020).

World Economic Forum. 2020. The Story of Viet Nam's Economic Miracle. Available online: https://www.weforum. org/agenda/2018/09/how-vietnam-became-an-economic-miracle/ (accessed on 26 April 2020).

Zarutskie, Rebecca. 2006. Evidence on the effects of bank competition on firm borrowing and investment. Journal of Financial Economics 81: 503-37. [CrossRef]

(C) 2020 by the authors. Licensee MDPI, Basel, Switzerland. This article is an open access article distributed under the terms and conditions of the Creative Commons Attribution (CC BY) license (http://creativecommons.org/licenses/by/4.0/). 